\title{
Evaluation of nickel and cobalt release from mobile phone devices used in Brazil*
}

\author{
Mariana de Figueiredo Silva Hafner ${ }^{1}$ \\ Rosana Lazzarini ${ }^{1}$
}

\author{
Jessica Chia Sin Chen ${ }^{2}$
}

\section{DOI: http://dx.doi.org/10.1590/abd1806-4841.20186800}

\begin{abstract}
Nickel and cobalt are often responsible for metal-induced allergic contact dermatitis. With the increasing use of cell phones, we observed an increase in cases reports on telephone-related allergic contact dermatitis. The present study evaluated nickel and cobalt release from mobile phones used in Brazil. We evaluated devices of 6 brands and 20 different models using nickel and cobalt allergy spot tests. Of the 20 models, $64.7 \%$ tested positive for nickel, with $41.1 \%$ positive results for the charger input and $23.5 \%$ for other tested areas. None of them was positive for cobalt. Nickel release was more common in older models.
\end{abstract} Keywords: Nickel; Cell phones; Cobalt

The use of mobile phones has increased exponentially in the last ten years. Data from the Brazilian Telecommunications Agency (Anatel) indicate that, in May 2016, Brazil recorded 255.23 million active mobile telephone lines. ${ }^{1}$ Currently, there are several models of mobile devices on the market, most of which contain metal. Therefore, the widespread use of cell phones has led to a situation in which metal cell phone parts may come into contact with the user's ear and face for prolonged periods of time. Thus, cases of cell phone allergic contact dermatitis (ACD) have been described in the literature.

Nickel and cobalt are the agents commonly responsible for metal-induced ACDs. The concomitance of positive tests to these elements occurs most often by co-sensitization, that is, simultaneous exposure to materials that contain them. ${ }^{2}$ Nickel is found in everyday objects such as keys, buckles, and buttons. It is a common allergen, accounting for about $24.5 \%$ of the positive tests obtained at specialized clinics in Brazil. ${ }^{2}$ The first report of a nickel-induced ACD case caused by a cell phone was described in 2000. Since then, other cases have been reported. ${ }^{3}$

In 1994 the European Union Nickel Directive was created to reduce the maximum permissible concentration of the metal in products of direct and prolonged contact with the consumer's skin. ${ }^{4}$ Since then, the prevalence of nickel ACD has decreased in some European countries. ${ }^{5,6}$ In 2009, the Directive was revised and applied to mobile phones. ${ }^{4}$
The objective of this study was to evaluate nickel and cobalt release from cellular devices used in a São Paulo, Brazil.

The devices were tested for nickel release using dimethylglyoxime (DMG) (Chemo Nickel Test ${ }^{\mathrm{TM}}$, Chemotechnique Diagnostics - Vellinge, Sweden), which detects the release of $0.5 \mu \mathrm{g} / \mathrm{cm}^{2} /$ week with sensitivity of $59 \%$ and specificity of $98 \%$. Cobalt, in turn, was investigated using Chemo Cobalt Test ${ }^{\mathrm{TM}}$ (Chemo Cobalt Test ${ }^{\mathrm{TM}}$, Chemotechnique Diagnostics - Vellinge, Sweden), which detects free cobalt down to a limit of $8 \mathrm{ppm}$. $^{7}$ The positivity of the tests is related to the minimum amount of metal required for triggering ACD in humans. In Brazil, only the nickel detection test is commercially available.

Using flexible cotton swabs, we applied DMG to all metal areas of the phones, which included camera, main button, side buttons, charger and earphone inputs, and sides.(Figure 1) After that, we cleaned the device with a dry cloth and repeated the procedure with nitroso R-salt. The test is considered positive when color changes occur (from white to pink, for nickel, and from yellow to red, for cobalt). In the absence of color change, the test is considered negative. Both tests evaluate whether there is metal release from the device and not whether they are present in the metal alloys. ${ }^{7}$

The tests were performed on 17 models ( 20 devices) of six different brands. Of these, 11 (64.7\%) tested positive for nickel, with 7 devices (41.1\%) releasing the metal only from the charger input

Received on 14.12.2016.

Approved by the Advisory Board and accepted for publication on 28.03.2017.

* Work performed at the Dermatology Clinic at Santa Casa de São Paulo - São Paulo (SP), Brazil.

Financial support: None.

Conflict of interest: None.

Dermatology clinic at Santa Casa de São Paulo - São Paulo (SP), Brazil.

Medical student of the School of Medical Sciences at Santa Casa de São Paulo - São Paulo (SP), Brazil.

MAILING ADDRESS:

Rosana Lazzarini

E-mail: rosana.fototerapia@gmail.com 


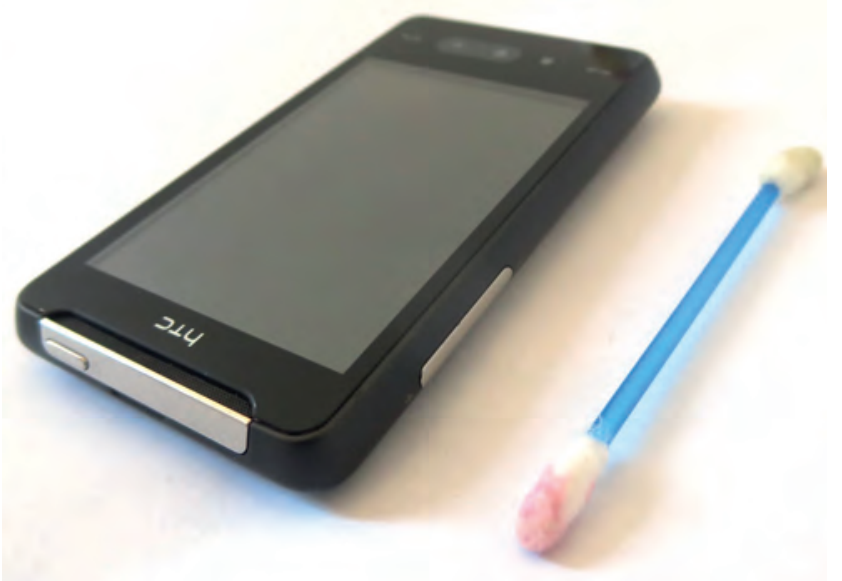

FIGURE 1: Positive test for nickel release from mobile devices and $4(23.5 \%)$ from other areas (earphone input, main button, side buttons, top edge, or camera). All tests for cobalt were negative. Table 1 contains the complete list of results.

Despite the efforts to control the release of allergens, some merketed phones release sufficient levels of nickel to induce ACD. ${ }^{6}$ In adults and children, it is important to suspect this diagnosis when the patient presents with eczema on the face, neck, hands, torso, and anterior aspect of the thighs.

Most of the cell phones tested in this study were smartphones, which are currently the most used models. Studies conducted in Europe showed that between $18 \%$ and $26 \%$ of the tested cell phones tested positive for nickel, with higher rates for non-smartphones. ${ }^{7}$ A study conducted in the United States found that 24 of $72(33 \%)$ cell phones yielded positive results for nickel. ${ }^{8}$ Our study presented higher results than the aforementioned studies (64.7\%). However, considering that a large part $(41.1 \%)$ of the models analyzed in our study showed positive results only for the charger input (greater wear and tear and reduced user contact), only $23.5 \%$ would be related to a possible ACD induction, which would

Table 1: Results of nickel and cobalt release in 20 mobile devices of different brands available in the Brazilian market in 2016

\begin{tabular}{|c|c|c|c|c|c|c|c|}
\hline Brand & Model & $\begin{array}{c}\text { Release } \\
\text { date }\end{array}$ & $\begin{array}{l}\text { Type of } \\
\text { device }\end{array}$ & $\begin{array}{l}\text { \# of } \\
\text { tested } \\
\text { devices }\end{array}$ & $\begin{array}{l}\text { \# }(\%) \text { of devices } \\
\text { tested positive } \\
\text { for nickel }\end{array}$ & $\begin{array}{l}\text { \# of areas tested } \\
\text { positive for } \\
\text { nickel }\end{array}$ & $\begin{array}{l}\text { \# ( } \%) \text { of devices } \\
\text { tested positive } \\
\text { for cobalt }\end{array}$ \\
\hline \multirow[t]{5}{*}{ Apple } & iPhone 4 & 2010 & Smartphone & 1 & 0 & & 0 \\
\hline & iPhone 5c & 2013 & Smartphone & 1 & $1(100 \%)$ & 1 (charger input) & 0 \\
\hline & iPhone 5s & 2013 & Smartphone & 1 & $1(100 \%)$ & 1 (charger input) & 0 \\
\hline & iPhone 6 & 2013 & Smartphone & 3 & $3(100 \%)$ & 1 (charger input) & 0 \\
\hline & iPhone 6s & 2015 & Smartphone & 2 & $2(100 \%)$ & 1 (charger input) & 0 \\
\hline \multirow[t]{6}{*}{ Samsung } & $\begin{array}{l}\text { Galaxy gran } \\
\text { prime duos }\end{array}$ & 2014 & Smartphone & 1 & $1(100 \%)$ & 1 (charger input) & 0 \\
\hline & $\begin{array}{l}\text { Galaxy core } 2 \\
\text { duos }\end{array}$ & 2012 & Smartphone & 1 & 0 & & 0 \\
\hline & Galaxy E3 & 2012 & Smartphone & 1 & $1(100 \%)$ & $\begin{array}{l}2 \text { (charger and } \\
\text { headphone } \\
\text { input) }\end{array}$ & 0 \\
\hline & Galaxy S6 & 2015 & Smartphone & 1 & $1(100 \%)$ & 1 (charger input) & 0 \\
\hline & $\mathrm{ACE}$ & 2012 & Smartphone & 1 & $1(100 \%)$ & $\begin{array}{l}2 \text { (charger and } \\
\text { headphone } \\
\text { input) }\end{array}$ & 0 \\
\hline & SGH J700i & 2008 & Flip phone & 1 & $1(100 \%)$ & $\begin{array}{l}3 \text { (main button, } \\
\text { side buttons, } \\
\text { camera) }\end{array}$ & 0 \\
\hline \multirow[t]{3}{*}{ LG } & G3 & 2014 & Smartphone & 1 & $1(100 \%)$ & 1 (charger input) & 0 \\
\hline & L80 & 2014 & Smartphone & 1 & 0 & & 0 \\
\hline & L70 & 2014 & Smartphone & 1 & 0 & & 0 \\
\hline Motorola & G3 & 2015 & Smartphone & 1 & 0 & & 0 \\
\hline HTC & HD mini t5555 & 2010 & Smartphone & 1 & $1(100 \%)$ & 1 (top edge) & 0 \\
\hline $\begin{array}{l}\text { Sony } \\
\text { Ericsson }\end{array}$ & Xperia X10 & 2009 & Smartphone & 1 & 0 & & 0 \\
\hline
\end{tabular}


approximate our results to those found in the European studies. It is worth noting that the cell phones that tested positive for nickel in more than one area in our study are non-smartphone and older models.

The present study detected no cobalt release from the analyzed devices. The data on the subject are divergent among studies. A Danish study that surveyed 50 brand new devices showed no metal release. On the other hand, Aquino et al. analyzed used devices and obtained positive results. ${ }^{8,9}$

Cell phone accessories were not tested in our study because they do not remain in contact with the user's skin no prolonged periods, ie exposure greater than 30 minutes of continuous or more than 1 hour total of discontinuous skin contact in a day. On the other hand, a recent study revealed through laboratory tests that frequent and short contacts are also capable of releasing sufficient quantities of nickel to cause skin reactions, although they consider that prolonged contact is still a major cause. ${ }^{10}$

As observed by Aquino et al. and also revealed by the present study, the finding of nickel in a small number of phone models cannot be extrapolated to the various other models. ${ }^{8}$ However, nickel release from some models, even in areas with little user exposure, should draw the attention of physicians, especially when the devices are handled by patients known to be allergic to metals.

\section{REFERENCES}

1. Anatel.gov.br [Internet]. Agência Nacional de Telecomunicações. Telefonia Móvel. Acessos [ acesso 23 Jul 2016]. Disponível em: http://www.anatel.gov.br/dados/ index.php/component/content/article?id=283

2. Duarte I, Mendonça R, Korles, K, Lazzarini, R, Hafner R. Nickel, chromium and cobalt: the prevalence of occupational and nonoccupational sensitization. Contact Dermatitis 2016:75:78.

3. Pazzaglia M, Lucente P, Vincenzi C, Tosti A. Contact dermatitis from nickel in mobile phone. Contact Dermatitis. 2000;42:362-3.

4. Thyssen JP, Johansen JD. Mobile phones are now covered by the European Union Nickel Directive. Contact Dermatitis. 2009;61:56-7.

5. Schnuch A, Uter W. Decrease in nickel allergy in Germany and regulatory interventions. Contact Dermatitis. 2003;49:107-8

6. Jensen P, Johansen JD, Zachariae C, Menné T, Thyssen JP. Excessive nickel release from mobile phones-a persistent cause of nickel allergy and dermatitis. Contact Dermatitis. 2011;65:354-8.

7. Fowler JF. Cobalt. Dermatitis. 2016;27:3-8

8. Aquino M, Mucci T, Chong M, Lorton MD, Fonacier L. Mobile phones: potential sources of nickel and cobalt exposure for metal allergic patients. Pediatr Allergy Immunol Pulmonol. 2013;26:181-186.

9. Thyssen JP, Menné T, Lidén C, Julander A, Jensen P, Jakobsen SS, et al. Cobalt release from implants and consumer items and characteristics of cobalt sensitized patients with dermatitis. Contact Dermatitis. 2012;66:113-22

10. Erfani B, Lidén C, Midander K. Short and frequent skin contact with nickel. Contact Dermatitis. 2015;73:222-30.

How to cite this article: Hafner MFS, Chen JCS, Lazzarini R. Evaluation of nickel and cobalt release from mobile phone devices used in Brazil. An Bras Dermatol. 2018;93(1):151-3. 